\title{
The Geology of the Faraday 1 Kimberlite, NWT, Canada
}

\author{
Lindsay Nelson', Casey Hetman², Michael Diering ${ }^{3}$ \\ ${ }^{1}$ Aurora Geosciences Ltd., Yellowknife, Canada, lindsay.nelson@aurorageosciences.com \\ ${ }^{2}$ SRK Consulting, Vancouver, Canada, chetman@srk.com \\ ${ }^{3}$ SRK Consulting, Vancouver, Canada, mdiering@srk.com
}

\section{Introduction}

The Faraday 1 kimberlite is located in the southeastern Slave Craton, approximately $10 \mathrm{~km}$ northeast of the Gahcho Kué Diamond Mine. The diamondiferous Faraday 1 body is part of the Kelvin-Faraday kimberlite cluster. Preliminary age-dating of the Kelvin kimberlite indicates a late Proterozoic to early Cambrian age of emplacement; it is probable that the Faraday kimberlites are contemporaneous, though no age-dating has been completed. Faraday 1 is the furthest towards the northeast of the pipes in the cluster and adjacent to the Faraday 3 kimberlite. The kimberlite subcrops below a shallow lake and is covered by a thin layer of lake-bottom sediments and glacial till. The host rock consists of metaturbidites of the Yellowknife Supergroup with minor amphibolite and narrow diabase dikes. Archean granitoids occur immediately to the west of the kimberlite cluster. Coherent kimberlite was first discovered in the Faraday 1 area by De Beers Canada in 2001. Since 2012, Kennady Diamonds Inc. has completed geophysical surveying and extensive drilling programs resulting in the discovery of volcaniclastic kimberlite and the delineation of the kimberlite complex. Faraday 1 has a tube-like shape that is inclined at $25^{\circ}$ towards the northwest; the central kimberlite body is over $190 \mathrm{~m}$ long and varies in width between 30 and $60 \mathrm{~m}$. The other kimberlites in the Kelvin-Faraday cluster also display non-typical inclined pipe morphologies with similar orientations and are dominantly infilled with volcaniclastic kimberlite. All of these pipes are associated with extensive hypabyssal kimberlite sheet systems, some of which have strike lengths exceeding $1000 \mathrm{~m}$. Faraday 1 is the smallest of the kimberlite pipes in the cluster, and it has the highest proportion of hypabyssal kimberlite associated with sheets.

\section{Evaluation}

Detailed logging of drill core, petrography, and microdiamond sampling were used to define the complex internal geology of Faraday 1 and produce a 3D model of the kimberlite (Figure 1). A total of 42 core holes and four 11-inch diameter reverse circulation (RC) holes were completed at Faraday 1. Drill core and RC samples were logged in detail using a binocular microscope. Representative samples from 20 holes across the body were selected for a petrographic investigation comprising 137 kimberlite thin sections and 54 country rock and marginal breccia thin sections. A total of 2,228 kg of kimberlite drill core was processed by caustic fusion at the Geoanalytical Laboratories Diamond Services of the Saskatchewan Research Council (SRC); the diamond recoveries are summarized in Table 1.

\begin{tabular}{|c|c|c|c|c|c|c|c|c|c|c|c|c|c|c|c|}
\hline \multirow[b]{2}{*}{ Unit } & \multirow{2}{*}{$\begin{array}{c}\text { Sample } \\
\text { Weight } \\
\text { (dry } \\
\text { tonnes) }\end{array}$} & \multicolumn{12}{|c|}{ Number of Diamonds According to Sieve Size Fraction (mm) } & \multirow[b]{2}{*}{$\begin{array}{c}\text { Total } \\
\text { Stones } \\
\end{array}$} & \multirow{2}{*}{$\begin{array}{c}\text { Total } \\
\text { Carats } \\
(+0.85 \\
\mathrm{mm}) \\
\end{array}$} \\
\hline & & $\begin{array}{r}+0.106 \\
-0.150 \\
\end{array}$ & $\begin{array}{r}+0.150 \\
-0.212 \\
\end{array}$ & $\begin{array}{l}+0.212 \\
-0.300 \\
\end{array}$ & $\begin{array}{l}+0.300 \\
-0.425 \\
\end{array}$ & $\begin{array}{r}+0.425 \\
-0.600 \\
\end{array}$ & $\begin{array}{l}+0.600 \\
-0.850 \\
\end{array}$ & $\begin{array}{r}+0.850 \\
-1.180 \\
\end{array}$ & $\begin{array}{l}+1.180 \\
-1.700\end{array}$ & $\begin{array}{l}+1.700 \\
-2.360 \\
\end{array}$ & $\begin{array}{l}+2.360 \\
-3.350 \\
\end{array}$ & $\begin{array}{r}+3.350 \\
-4.750 \\
\end{array}$ & $\begin{array}{r}+4.750 \\
-6.700 \\
\end{array}$ & & \\
\hline KDYKE & 0.2694 & 688 & 419 & 248 & 146 & 87 & 44 & 20 & 13 & 1 & - & - & 1 & 1,667 & 2.1567 \\
\hline KIMB1 & 1.0049 & 1,006 & 671 & 368 & 211 & 113 & 57 & 37 & 20 & 8 & 6 & - & - & 2,497 & 3.2036 \\
\hline KIMB2 & 0.1128 & 236 & 155 & 95 & 56 & 27 & 23 & 12 & 5 & 3 & 1 & - & - & 613 & 1.1692 \\
\hline KIMB3 & 0.2809 & 940 & 547 & 309 & 188 & 101 & 67 & 29 & 13 & - & - & - & - & 2,194 & 0.6536 \\
\hline KIMB4 & 0.0838 & 124 & 75 & 56 & 27 & 15 & 8 & 4 & 3 & 1 & - & - & - & 313 & 0.2021 \\
\hline KIMB5 & 0.1781 & 245 & 164 & 85 & 71 & 38 & 25 & 13 & 5 & 1 & 1 & - & - & 648 & 0.6518 \\
\hline MB & 0.2977 & 82 & 55 & 27 & 10 & 3 & 1 & 2 & - & - & - & - & - & 180 & 0.0162 \\
\hline
\end{tabular}

Table 1: Summary of diamond recovery results by unit. 


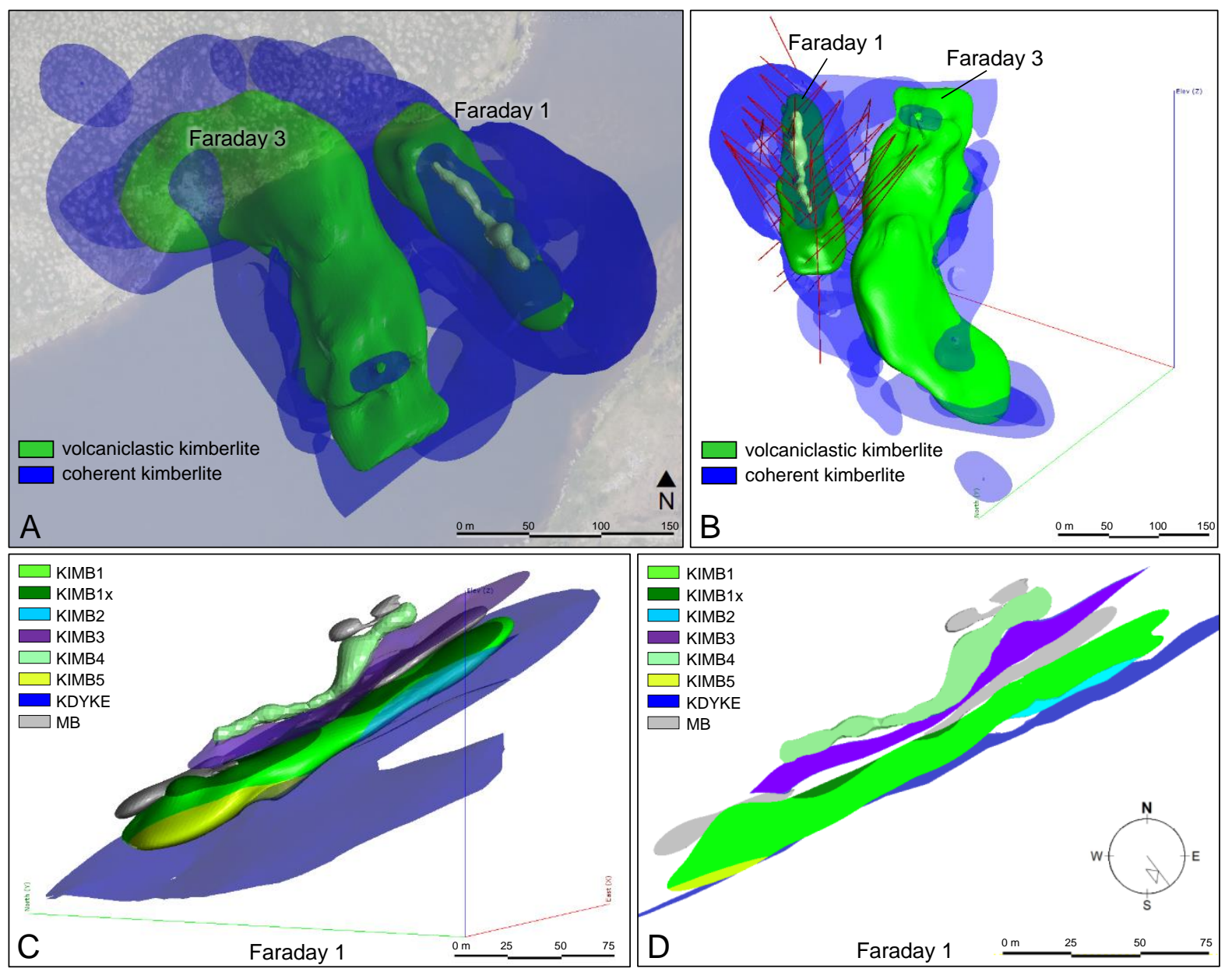

Figure 1: 3D model of the Faraday 1 kimberlite and associated Faraday 3 pipe. (A) Plan view with the surrounding hypabyssal sheet complex; (B) Oblique view of the Faraday 1 and 3 kimberlites, looking southeast, with the traces of diamond drill holes on the Faraday 1 kimberlite; (C) Detailed geology model of Faraday 1 looking northeast; KIMB1: volcaniclastic phlogopite kimberlite, KIMB1x: variation of KIMB1 with high country rock dilution, KIMB2: coherent phlogopite kimberlite with coherent kimberlite autoliths and 3-10\% country rock, KIMB3: coherent phlogopite-monticellite kimberlite, KIMB4: volcaniclastic to transitional phlogopite kimberlite, KIMB5: volcaniclastic to transitional phlogopite kimberlite with coherent kimberlite autoliths, KDYKE: hypabyssal kimberlite sheet, MB: marginal breccia. (D) Long section of Faraday 1 looking northeast.
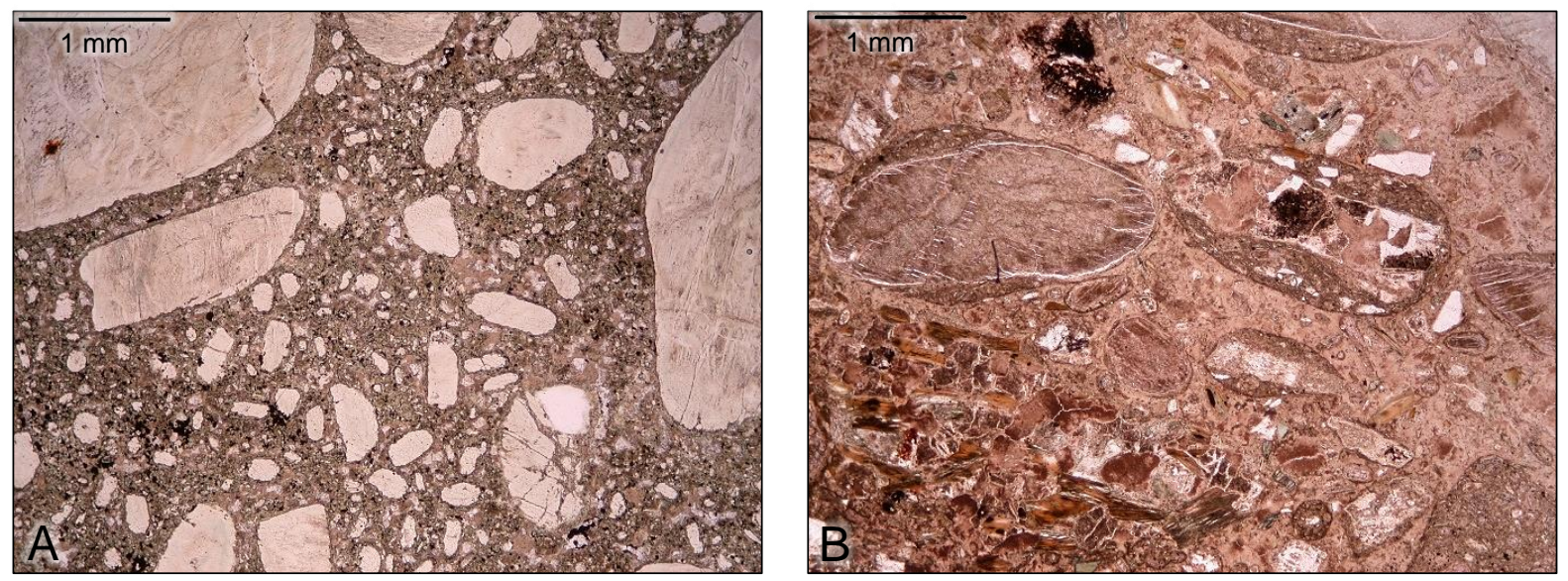

Figure 2: Photomicrographs of the two textural end-members at Faraday 1. (A) Coherent phlogopite-monticellite kimberlite (KIMB3); olivine-rich with a crystalline groundmass containing segregations of serpentine and carbonate. (B) Volcaniclastic phlogopite kimberlite (KIMB1); olivine-rich with abundant country rock shards and well-developed pelletal-shaped magmaclasts. 


\section{Geology}

Faraday 1 is a complex volcanic system containing both coherent rocks and rocks formed by explosive fragmentation processes. The dominant rock types are a fine- to coarse-grained olivine-rich phlogopitemonticellite hypabyssal kimberlite (KIMB3) and a fine- to medium-grained olivine-rich volcaniclastic phlogopite kimberlite (KIMB1). KIMB3 is characterized by a uniform olivine distribution and welldeveloped crystalline groundmass containing phlogopite, spinel, and monticellite with irregular segregations of serpentine and carbonate. Country rock dilution is visually estimated at 0-5\%. Mantlederived indicator minerals are rare and primarily consist of peridotitic garnet. KIMB1 contains distinctive pelletal-shaped magmaclasts with well-formed elongate phlogopite laths in the melt selvages; the rock is massive and unsorted with $30-60 \%$ dilution by country-rock xenoliths. Country rock xenoliths consist of locally-derived metaturbidite and amphibolite with rare diabase and granitoid. A number of minor kimberlite units have also been identified (Figure 1: KIMB2, KIMB4, KIMB5). These units encompass a range of textures from coherent to transitional and volcaniclastic. There is also a marginal breccia (MB) composed of angular locally-derived xenoliths set within a fine-grained, variably-sorted matrix of pulverized country rock with trace amounts of kimberlitic material.

The spatial relationships between the rock units of Faraday 1 are complicated. KIMB1, KIMB2, and KIMB5 infill the central tube-shaped pipe, which is surrounded by layers of shallowly-dipping hypabyssal kimberlite sheets and a small external volcaniclastic body (Figure 1). Sharp contacts and cross-cutting relationships exist between kimberlite units, indicating the presence of multiple phases of kimberlite related to distinct emplacement events.

\section{Conclusions}

Following detailed petrography, volcaniclastic rocks at Faraday 1 are further classified as Kimberleytype pyroclastic kimberlite (KPK), formerly called tuffisitic kimberlite breccia (TKB) (Smith et al., 2013). The association of hypabyssal kimberlite sheets with volcaniclastic pipes is typical of KPK systems worldwide. However, the inclined orientation of the Faraday 1 pipe is unusual outside of the Kelvin-Faraday cluster.

The textures, mineralogy, and significantly diamondiferous nature of the kimberlite units at Faraday 1 are similar to the other bodies in the Kelvin-Faraday cluster and the Gahcho Kué kimberlite cluster (Hetman et al. 2004).

Faraday 1 is the least volcanically mature of the kimberlite pipes in the cluster discovered to date. It is dominated by thick hypabyssal kimberlite sheets and irregular intrusions layered with thin volcaniclastic units, and marginal breccia. Intervals of intact country rock are present between kimberlite units; in some cases, it cannot be determined if these intervals are in-situ or represent xenoliths.

Faraday 1 is open at depth, and additional drilling is required to establish the full extent of the kimberlite. The first bulk sample from Faraday 1 was completed in 2017, with the collection of 25 tonnes of kimberlite by 11-inch reverse circulation drilling. The macrodiamond results from this sample will provide further information about the grade and preliminary diamond value that will be used to support a possible resource classification.

\section{References}

Hetman, C. M., Smith, B. S., Paul, J. L., \& Winter, F. (2004). Geology of the Gahcho Kue kimberlite pipes, NWT, Canada: root to diatreme magmatic transition zones. Lithos, 76(1), 51-74.

Smith, B. S., Nowicki, T. E., Russell, J. K., Webb, K. J., Mitchell, R. H., Hetman, C. M., and Robey, J. A. (2013). Kimberlite terminology and classification. In Proceedings of 10th International Kimberlite Conference (pp. 1-17). Springer India. 